\title{
Analisis Strategi Pemasaran Dalam Upaya Peningkatan Daya Saing Umkm
}

\author{
Sulistiyani ${ }^{1}$ Aditya Pratama ${ }^{2}$ \\ Setiyanto ${ }^{3}$ \\ Universitas Pamulang ${ }^{1}$ Universitas Negeri Jakarta ${ }^{2}$ \\ Emaill : sulizbimbi@gmail.com
}

\begin{abstract}
Abstrak. Strategi pemasaran mempunyai peran penting bagi UMKM. Peran penting dari strategi pemasaran yang tepat akan mampu meningkatkan daya saing produk yang dihasilkan UMKM. Dalam upaya menuyusun strategi pemasaran dibutuhkan informasi yang lengkap berkaitan dengan pasar, konsumen maupun produk yang dibutuhkan. Tidak adanya informasi yang mendukung dalam penentuan strategi pemasaran tentu saja membuat UMKM sulit bersaing. Tujuan penelitian ini untuk menganalisis penerapan strategi pemasaran dalam upaya peningkatan daya saing UMKM. Metode analisis: menggunakan pendekatan dekriptif dengan metode kualitatif melalui tahapan reduksi data, penyajian data dan penarikan kesimpulan dengan menggunakan analisis SWOT. Hasil penelitian ini adalah, Wilayah pemasaran produk yang dipilih pada industri keripik pisang Tunas Metro adalah wilayah Metro dan sekitarnya Hal ini disebabkan keterbatasan modal yang dimiliki home industri kripik pisang tunas. strategi pemasaran yang dilakukan oleh home industri kripik hanya dengan kedekatan personal maupun penjualan yang ada di toko saja. Minimnya kemampuan pemahaman dan pengelolaan dari segi digital atau ecommarace yang membuat pemilik belum memanfaatkan media yang ada secara optimal. Berdasarkan analisis SWOT yang dilakukan pada UKM keripik pisang tunas Metro, maka beberapa strategi telah dirumuskan dalam upaya meningkatkan daya saing diantaranya sebagai berikut; Mempertahankan harga dan kualitas produk untuk meningkatkan loyalitas konsumen; Menjalin kerjasama yang saling menguntungkan untuk memperluas wilayah pemasaran; Meningkatkan jumlah produksi menjelang musim kemarau; Menjaga kualitas produk; merubah desain kemasan supaya lebih menarik konsumen; Memanfaatkan perkembangan teknologi sebagai sarana promosi; Meningkatan modal usaha untuk memperluas wilayah pemasaran dan menambah jumlah produksi; Melakukan perluasan wilayah pemasaran dan melakukan promosi untuk menarik konsumen.
\end{abstract}

Kata Kunci: Strategi Pemasaran; Daya Saing; UMKM

Abstract. The marketing strategy has an important role for MSMEs. The important role of the right marketing strategy will be to increase the competitiveness of products produced by MSMEs. In an effort to compile a marketing strategy, it needs complete information with the markets, consumers and products needed. The absence of information that supports marketing strategies alone makes it difficult for SMEs to compete. The purpose of this study is to analyze the application of marketing strategies in an effort to improve the 
competitiveness of MSMEs. Method of analysis: using descriptive discussions with qualitative methods through the stages of data reduction, data presentation and conclusions using SWOT analysis. The results of this study are, the selected product marketing area in the Tunas Metro banana chips industry is the Metro area and its surroundings This is related to the limited capital needed by the tuna banana chips home industry. marketing strategies carried out by the home crisp industry only with personal closeness or sales in the store alone. The lack of ability to understand and manage from digital or e-commerce makes the owner has not used the existing media optimally. Based on the SWOT analysis conducted on SME of Metro shoots banana chips, then several strategies must be formulated in an effort to improve competitiveness as follows; Maintaining price and product quality to increase customer loyalty; Establish mutually beneficial cooperation to expand the marketing area; Increasing the amount of production increases in the dry season; Maintain product quality; change the packaging design. Utilizing technological developments as a means of promotion; Increase business capital to expand the marketing area and increase the amount of production; Conduct marketing withdrawals and promotions to attract consumers.

Keywords: Marketing Strategy; Competitiveness; MSME

\section{A. PENDAHULUAN}

UMKM memberikan sumbangsih terhadap perekonomian negara. Kontribusi yang diberikan UMKM tentu saja mengurangi beban tanggung jawab pemerintah sebagai penyedia lapangan kerja bagi masyarakatnya. Maka UMKM harus diberi dukungan untuk dapat mengembangkan unit usahanya. Tidak hanya menyumbangkan pajak dalam jumlah besar, UMKM juga mampu mengurangi tingkat pengangguran yang ada di Indonesia.

Dukungan dalam pengembangan UMKM tentu saja harus dilakukan. Pendirian UMKM merupakan salah satu salusi yang bisa mengatasi masalah baik masalah perekonomian ataupun masalah pengangguran. Strategi dalam upaya pengembangan UMKM tentu saja harus lebih ditingkatkan. Pemberdayaan Usaha Kecil dan Menengah (UKM) mampu menjadi pendorong pertumbuhan kegiatan ekonomi masyarakat, dan dapat menjadi salah satu sumber pendapatan masyarakat untuk meningkatkan tingkat kesejahteraan (SAPUTRI, 2014). Salah satu upaya untuk mendukung pengembang UMKM adalah pemberian pinjaman uang berupa kredit lunak dengan bunga rendah. Berdasarkan pendapat Pratama (2015) menjelaskan bahwa pemberian kredit mampu meningkatkan pendapan UMKM.

Tidak hanya dibidang keuangan saja salah satu upaya untuk peningkatan daya saing UMKM. Peranan UMKM yang begitu besar mampu menjelaskan bahwa UMKM perlu dukungan untuk peningkatan kualitasnya. UMKM yang mampu bertahan dan bersaing di dunia usaha tentu saja memiliki pengelolaan manajemen yang baik. Secara umum pengelolaan manajemen mencangkup sistem pemasaran, produksi dan manajemen Sumber Daya Alam (SDA) dan Sumber Daya Manusia (SDM).

Penyusunan strategi membutuhkan konsep dan perencanaan yang baik salah satu kunci UMKM untuk memenangkan persaingan. Konsep dan perencanaan untuk menganalisis pasar harus disusun secara tepat supaya mampu memberikan informasi yang dibutuhkan. Informasi berkaitan dengan pasar, pembeli dan produk yang dibutuhkan sangat dibutuhkan dalam penentuan strategi pemasaran bagi UMKM. 
Keberhasilan UMKM dapat dilihat dari keberhasilan dalam penentuan kebijakan yang tepat dari proses penentuan produk, harga, promosi serta saluaran distribusi yang efektif (Wibowo, Arifin dan Sunarti, 2015). Strategi pemasaran merupakan unsur penting dalam proses pemasaran produk. Strategi pemasaran yang tepat akan mampu membeirkan kontribusi pada penjualan produk UMKM. Dari produk yang terjual merupakan sumber utama UMKM untuk bertahan dan bersaing dari ketatnya persaingan di dunia usaha.

Dari penjelasan diatas ada beberapa rumusan masalah yang akan dicari kesimpulan di dalam penelitan ini adalah sebagai berikut: 1. Bagaimana penerapan strategi pemasaran dalam upaya peningkatan daya saing UMKM. 2. Bagaimana pengembangan strategi pemasaran dalam upaya peningkatan daya saing UMKM. 3. Bagaimana kekuatan, kelemahan, peluang dan hambatan yang secara rill dimiliki UMKM

Tujuan penelitian mengacu pada latar belakang dan rumusan masalah penelitian. Adapun tujuan dari penelitian ini adalah sebagai berikut: 1. Menganalisis penerapan strategi pemasaran dalam upaya peningkatan daya saing UMKM. 2. Menganalisis pengembangan strategi pemasaran dalam upaya peningkatan daya saing UMKM. 3. Menganalisis kekuatan, kelemahan, peluang dan hambatan yang secara rill dimiliki UMKM

\section{B. KAJIAN LITERATUR}

\section{UMKM}

UMKM merupakan unit usaha yang sangat populer di kalangan masyarakat. UMKM merupakan unit usaha mulai dari yang paling kecil yang disebut juga mikro. Usaha ini dapat dimiliki perseorangan maupun badan. Kriteria dalam usaha mikro ini yaitu memiliki modal bersih sebanyak Rp 50.000 .000 dan hasil penjualan pertahun tidak lebih dari Rp 30.000.000. Usaha mikro juga bisa bisa dimiliki oleh perorangan maupun badan yang memiliki kriteria yaitu modal bersih lebih dari Rp. $50.000 .000,00$ (lima puluh juta rupiah) sampai dengan paling banyak $\mathrm{Rp}$. 500.000 .000 dan hasil penjualan paling banyak Rp. 2.500.000.000. sedangkan untuk usaha mengah juga bisa dimiliki perorangan maupun badan yang memiliki kriteria yaitu modal bersih lebih dari Rp. 500.000 .000 sampai dengan paling banyak Rp. 10.000.000.000 dan hasil penjualan tahunan lebih dari Rp. 2.500.000.000 sampai dengan paling banyak Rp. 50.000.000.000. hal tersebut sudah diatur oleh pemerintah dalam Undang-undang No. 20 Tahun 2008.

\section{Daya Saing}

Daya saing merupakan suatu upaya yang harus dilakukan oleh pelaku usaha/ekonomi agar tetap eksis dalam menjalankan kegiatannya (Asmara \& Rahayu, 2013). Daya saing terutama bila dilihat dari segi produk tentu saja wajib dimiliki oleh UMKM. Karena daya saing tersebut mampu membawa UMKM tetap bertahan dalam ketatnya persaingan di dunia usaha.

Keempat dimensi daya saing suatu perusahaan sebagai berikut :

a. Biaya adalah dimensi daya saing operasi yang meliputi empat indikator yaitu biaya produksi, produktifitas tenaga kerja, penggunaan kapasitas produksi dan persediaan. Unsur daya saing yang terdiri dari biaya merupakan modal yang mutlak dimiliki oleh suatu perusahaan yangencakup pembiayaan produksinya, 
produktifitas tenaga kerjanya, pemanfaatan kapasitas produksi perusahaan dan adanya cadangan produksi (persediaan) yang sewaktu-waktu dapat dipergunakan oleh perusahaan untuk menunjang kelancaran perusahaan tersebut.

b. Kualitas seperti yang dimaksudkan oleh Muhardi adalah merupakan dimensi daya saing yang juga sangat penting, yaitu meliputi berbagai indikator diantaranya tampilan produk, jangka waktu penerimaan produk, daya tahan produk, kecepatan penyelesaian keluhan konsumen, dan kesesuaian produk terhadap spesifikasi desain. Tampilan produk dapat tercermin dari desain produk atau layanannya, tampilan produk yang baik adalah yang memiliki desain sederhana namun mempunyai nilai yang tinggi. Jangka waktu penerimaan produk dimaksudkan dengan lamanya umur produk dapat diterima oleh pasar, semakin lama umur produk di pasar menunjukkan kualitas produk tersebut semakin baik. Adapun daya tahan produk dapat diukur dari umur ekonomis penggunaan produk.

c. Waktu penyampaian merupakan dimensi daya saing yang meliputi berbagai indikator diantaranya ketepatan waktu produksi, pengurangan waktu tunggu produksi, dan ketepatan waktu penyampaian produk.

d. Fleksibilitas merupakan dimensi daya saing operasi yang meliputi berbagai indikator diantaranya macam produk yang dihasilkan, kecepatan menyesuaikan dengan kepentingan lingkungan.

Manfaat daya saing dalam lingkungan persaingan yang semakin kompetitif dan adanya situasi pasar yang dinamis, maka setiap perusahaan tidak mungkin lagi untuk menghindari persaingan, tetapi yang harus dilakukan adalah menghadapi tingkat persaingan tersebut dengan cara yang sebaik-baiknya. Sebaik-baiknya disini diartikan sebagai upaya yang dilakukan secara optimal dan berkesinambungan untuk menghasilkan sesuatu yang lebih baik dan lebih baik lagi di masa yang akan datang. Ada Empat Strategi Meningkatkan Kemampuan Daya Saing, Keahlian teknikal individu, Model dan strategi bisnis, Kemampuan teknologi dan inovasi, Kemampuan pemasaran (Asmara \& Rahayu, 2013).

\section{Strategi Pemasaran}

Penyusunan sebuah strategi merupakan langkah awal yang digunakan untuk mencapai apa yang sudah ditentukan. Strategi pemasaran mampu menggambarkan serangkaian kegiatan dalam mencapai tujuan yang sudah ditentukan,serangkaian kegiatan yang tentu saja merupakan hasil suatu kebijakan yang menjadi aturan yang dipergunakan selama periode tertentu (Wibowo, Arifin, \& Sunarti, 2015) (Ratnawati et al., 2017).

Ratnawati et al., (2017) ada tiga cara yang bisa digunakan untuk membuat strategi pemasaran yaitu strategi segmentasi pasar yang membagi pasar kedalam kelompok yang mempunyai karakteristik yang berbeda. Kemudian strategi penentuan pasar sasaran merupakan kegiatan menentukan pasar yang akan dituju setelah proses segmentasi pasar selesai. Kemudian ada strategi penentuan posisi pasar dalam strategi ini UMKM harus memiliki cara untuk memperoleh perhatian dari konsumen agar tertarik dengan produk yang telah dihasilkan. 


\section{METODOLOGI PENELITIAN}

1. Pendekatan Penelitian

Pendekatan yang dipakai di penelitian ini yatu pendekatan dekriptif dengan metode kualitatif. Pendekatan ini melalui cara mencari hubungan dari suatu keadaan dengan memperhatikan segala aspek yang mampu menggambarkan suatu keadaan secara nyata yang mampu memberikan informasi yang dibutuhkan.

2. Populasi dan Sampel

Pemilik usaha kripik pisang tunas di Kota Metro. Sampel dalam penelitian ini adalah pemilik usaha UMKM kripik pisang tunas di sentra home industri Di Kota Metro Lampung.

3. Jenis, Sumber dan Teknik Pengumpulan Data

Data yang digunakan merupakan data primer dan data kualitatif yang di ambil sumber data yang di peroleh langsung dari pemilik usaha yang bisa menjelaskan kondisi usaha secara terperinci.

4. Analisis SWOT

Analisis SWOT merupakan analisis dalam manajemen strategi yang didasarkan untuk mengetahui adanya peluang, ancaman, kekuatan dan kelemahan UMKM melalui analisa pengamatan lingkungan internal dan lingkungan eksternal. analisis SWOT merupakan prosedur sistematis untuk mengidentifikasikan peluang UMKM yang dilihat dari kekuatan (Strenght) dan kelemahan (Weakness) sebagai faktor internal, dan peluang (Opportunities) serta ancaman (Threats) sebagai faktor yang bersifat eksternal.

\section{HASIL DAN PEMBAHASAN}

Hasil penelitian ini adalah Wilayah pemasaran produk yang dipilih oleh industri keripik pisang Tunas Metro adalah wilayah Metro dan sekitarnya Hal ini disebabkan keterbatasan modal yang dimiliki home industri kripik pisang tunas. strategi pemasaran yang dilakukan oleh home industri kripik hanya dengan kedekatan personal maupun penjualan yang ada di toko saja. Minimnya kemampuan pemahaman dan pengelolaan dari segi digital atau e-commarace yang membuat pemilik belum memanfaatkan media yang ada secara optimal.

Dari hasil analasis yang dilakukan pada home industri Kripik Pisang Tunas tersebut maka dapat dipilih strategi pemasaran yang dapat dijadikan sebagai upaya peningkatan daya saing. Berikut ini hasil analisis yang dijabarkan sebagai berikut:

1. Strategi Strength dan Opportunities (SO)

Strategi SO dilakukan dengan cara menggabungkan antara Strength dan Opportunity untuk memanfaatkan kekuatan dan peluang yang dimiliki home industri Kripik Pisang Tunas, guna menangkap peluang yang dimiliki home industri Kripis Pisang Tunas.

a. Mempertahankan harga produk untuk meningkatkan loyalitas konsumen. Strategi tersebut ditentukan setelah menganalisis S1, S2, S3, O2, O3 pada matriks SWOT. Harga merupakan faktor penentu dari jumlah produk yang akan dijual. Apabila kita mengacu pada hukum permintaan yang berbunyi: jika harga naik maka permintaan akan turun dan sebaliknya jika harga turun maka permintaan akan naik. Harga dari kripik pisang tunas ini sangat terjangkau, 
dengan harga Rp 10.000 mendapatkan 1 bungkus kripik dengan berat 175 gram dengan beraneka ragam pilihan rasa. Jika tidak ada perubahan harga maka sudah dipastikan loyalitas konsumen akan selalu ada.

b. Mempertahankan kualitas produk untuk meningkatkan loyalitas konsumen. Strategi tesebut ditentukan setelah mengalisis S1, S2, S3, O2, O3 pada matriks SWOT. Konsumen tentu saja memiliki selera masing-masing bekaitan dengan sebuah. Konsumen apabila sudah menemukan sebuah produk yang sesuai dengan selera maka keputusan pembelian akan diambil. Kualitas produk menjadi salah satu faktor penting bagi sebuah produk. Apabila dikaitkan dengan selera konsumen maka bisa ditarik kesimpulan bahwa apabila seorang konsumen sudah menemukan suatu produk yang sesui dengan selera dan produk tesebut mampu mempetahankan kualitas produknya maka loyalitas akan terbentuk.

c. Menjalin kerjasama yang saling menguntungkan untuk memperluas wilayah pemasaran strategi tesebut ditentukan setelah mengalisis S1, S2, S3, O2, O4 pada matriks SWOT. Berdasarkan hasil wawancara terlihat bahwa pemilik home industri kripik pisang tunas merasa keberatan dengan sistem pembayaran produknya. Kerjasama tidak memberatkan salah satu pihak tenju saja merupakan kerjasama yang saling menguntungkan. Sebelum melakukan kerjasama tentu saja harus mendiskusikan segala hal kata sepakat telah muncul. Tentu saja dalam negoisasi harus saling memberikan keuntungan kepad semua pihak.

\section{Strategi Strength dan Treats (ST)}

Strategi ST ini merupakan penggunaan kekuatan yang dimiliki home industri Kripis Pisang Tunas digunakan untuk mengahadapi ancaman dari para pesaingyang mungkin dapat dihadapi "home industri Kripis Pisang Tunas.

a. Meningkatkan jumlah produksi menjelang sebelum terjadinya musim kemarau strategi tesebut ditentukan setelah mengalisis (S4, S5, T1) pada matriks SWOT. Daya saing UMKM dapat dilihat dari produk yang dihasilkan. Produk yang memiliki kualitas yang baik tentu saja mempunyai daya saing yang unggul. Produk yang memiliki harga yang murah memiliki daya terik tersendiri. Namun produk yang memiliki kualitas baik dan harga yang murah tidaklah cukup untuk memenangkan persaingan. Maka disinilah pentingnya jumlah produk yang dapat dihasilkan suatu UMKM untuk melengkapi keunggulan-keunggulan yang sudah dimiliki.

b. Terus berinovasi pada bentuk dan rasa produk strategi tesebut ditentukan setelah mengalisis S2, S3, T2 pada matriks SWOT. Apabila kita kaitkan dengan prilaku konsumen akan terjadi suatu pembahasan yang baru. Kepuasan konsumen akan suatu produk akan semakin menurun seiring seringnya konsumen mengkonsumsi suatu produk. Sejalan dengan daur hidup produk, produk akan memiliki suatu masa dimana produk tersebut sudah tidak diminati oleh konsumen. Disinilah pentingnya berinovasi pada bentuk dan rasa supaya loyalitas konsumen tetap terjaga.

\section{Strategi Weakness dan Opportunities (WO)}

Strategi WO ini digunakan pada saat adanya peluang yang dimiliki home industri Kripis Pisang Tunas guna mengatasi ancaman usaha home industri Kripis Pisang Tunas. 
a. Merubah desain kemasan supaya lebih menarik konsumen strategi tesebut ditentukan setelah mengalisis (W1, O2, O3, O4) pada matriks SWOT. Seiring perkembangan teknologi desain maupun bentuk kemasan suatu produk dapat dibuat semenarik mungkin guna menarik minat pembeli. Kripik pisang tunas memiliki desain kemasan dari awal pendirian sampai sekarang tidak mengalami perubahan. Segala faktor dalam upaya peningkatan daya saing tentu saja harus delengkapi salah satunya dengan melakukan perubahan desain kemasan tentu saja dapat lebih menarik perhatian konsumen.

b. Memanfaatkan perkembangan teknologi sebagai sarana promosi dan penjualan produk strategi tesebut ditentukan setelah mengalisis $\mathrm{W} 2, \mathrm{~W} 4, \mathrm{O} 2, \mathrm{O} 3, \mathrm{O} 7$ pada matriks SWOT. Kripik pisang tunas tidak menggunakan teknologi dalam mempromosikan produknya. Padahal dengan menggunakan teknologi dalam kegiatan promosi justru memberikan keuntungan yang sangat banyak. Keuntungan tersebut dapat dilihat dari segi biaya yang murah, perluasan wilayah pemasaran yang tidak terbatas. Teknologi di sini yang dimaksud adalah menggunakan media sosial dalam rangka mempromosikan produk yang dimilikinya. Media sosial juga bisa digunakan untuk kegiatan penjualan produk. Penjualan produk melalui media sosial tentu saja akan memberikan banyak sekali keuntungan seperti tidak perlu membayar pajak, wilayah pemasaran yang tidak terbatas dan mampu mendapatkan konsumen dalam jumlah banyak.

c. Meningkatan modal usaha untuk memperluas wilayah pemasaran strategi tesebut ditentukan setelah mengalisis W2, W3, W5, O2, O3, O4, O7 pada matriks SWOT. Perluasan wilayah pemasaran tentu saja membutuhkan biaya tidak sedikit. Sebagai contoh apabila proses pengiriman produk apabila ada pesanan dari luar kota tentu saja akan membutuhkan ongkos yang lebih banyak pada kegiatan tersebut. Maka disitulah pentingnya penambahan modal untuk perluasan wilayah pemasaran guna meningkatkan daya saing UMKM

d. Meningkatkan modal usaha untuk menambah jumlah produksi strategi tesebut ditentukan setelah mengalisis W3, W4, O1, O5, O6 pada matriks SWOT. Output yang dihasilkan tentu saja tergantung dengan jumlah input yang digunakan. Artinya penambahan variabel cost untuk meningkatkan jumlah produksi membutuhkan penambahan biaya. Contohnya penambahan bahan baku, penambahan tenaga kerja hal tesebut tentu saja akan memberikan dampak terhadap produk yang akan dihasilkan.

4. Strategi Weakness dan Treats (WT

Strategi WT ini digunakan saat home industri Kripis Pisang Tunas dalam hal mengatasi kelemahan yang dimiliki unit usaha tersebut agar terhindar dari ancaman usaha yang akan dihadapi.

a. Melakukan perluasan wilayah pemasaran dan melakukan promosi untuk menarik konsumen strategi tesebut ditentukan setelah mengalisis S2, S5, T2 pada matriks SWOT. Perluasan wilayah pemasaran dapat dilakukan dengan berbagai cara. Cara yang paling mudah dan murah iyalah menggunakan media sosial. Dengan menggunakan media sosial akan mampu mempercepat wilayah pemasaran produk tersebut. Dengan adanya perluasan wilayah pemasaran tentu saja akan mendatangkan konsumen baru. Cara menarik perhatian konsumen baru supaya tertarik membeli produk kripik pisang tunas adalah bisa dengan melakukan promosi berupa diskon. 


\section{E. KESIMPULAN}

Berdasarkan hasil pembahasa di atas dapat ditarik kesimpulan sebagai berikut ini:

1. Strategi pemasaran yang saat ini digunakan oleh UMKM kripik pisang "Tunas" masih terbilang sangat konvensional dan masih sangat sederhana. Dengan cara menjual produknya di toko di depan rumah pemilik UMKM keripik pisang "Tunas".

2. Kekuatan yang di miliki UMKM keripik pisang "Tunas" yaitu harga yang murah, rasa beraneka ragam, bentuk yang menarik, bahan baku mudah di dapat, proses pembuatan cepat, kualitas terjada. Sedangkan kelemahan yang dimiliki adalah kemasan kurang menarik, kurangnya media promosi pemasaran, keterbatasan modal, dikerjakan manual, wilayah pemasaran sempit. peluang yaitu tenaga kerja mudah diperoleh, banyaknya konsumen mencari oleh-oleh, tingginya loyalitas konsumen, banyaknya toko oleh-oleh, harga bahan baku murah, ketersediaan bahan baku melimpah, banyaknya media e-commerce. Sedangkan ancaman adalah kelangkaan bahan baku pada musim kemarau, pesaing usaha sejenis.

3. Strategi yang dapat digunakan UMKM keripik pisang "Tunas" dalam upaya peningkatan daya saing berdasarkan matriks SWOT yaitu dengan menjalin kerja sama yang saling mengguntungkan, memperluas wilayah pemasaran. Menjaga kualitas, terus berinovasi dalam bentuk dan rasa, memanfaatkan media sosial ataupun e-commerace sebagai sarana untuk melakukan promosi, memperluas pasar dan menarik konsumen.teoritis maupun praktis. Simpulan hendaknya merupakan jawaban atas pertanyaan penelitian, dan diungkapkan bukan dalam kalimat statistik.

\section{DAFTAR PUSTAKA}

Asmara, A. Y., \& Rahayu, S. (2013). Meningkatkan Daya Saing Industri Kecil Menengah Melalui Inovasi Dan Pemanfaatan Jaringan Sosial: Pembelajaran Dari Klaster Industri Software Di India. Seminar Nasional \& Call For Papers (Sca-3), (2005). Retrieved From Http://Jp.Feb.Unsoed.Ac.Id/Index.Php/Sca1/Article/Viewfile/254/259

BPS.https://www.google.com/url?sa $=t \& r c t=j \& q=\& e s r c=s \&$ source=web\&cd $=3 \& c a d=r j a \& u$ act=8\&ved=2ahUKEwik64zD0uDhAhXPbX0KHWImB3cQFjACegQIARAC\&url=ht tp\%3A\%2F\%2Fwww.turc.or.id\%2Fwpcontent\%2Fuploads\%2F2018\%2F06\%2FBPS_Berita-Resmi-Statsitik_KeadaanKetenagakerjaan-Indonesia-Februari2018.pdf\&usg=AOvVaw3efDJPxg_hVQJxITgE1u9E

Kemenperin. http://www.kemenperin.go.id/artikel/14200/Kontribusi-UMKM-Naik

Liputan 6. Com. 2018. https://www.liputan6.com/bisnis/read/3581067/umkm-sumbang60-persen-ke-pertumbuhan-ekonomi-nasional

Pratama. Aditya. 2015. Kontribusi Pemberian Kredit Dan Kemampuan Manajerial Terhadap Pendapatan UMKM Di Kota Madiun Tahun 2015. Jurnal Mandiri.

Ratnawati, A. Y., Kom, S., Susena, M. M. E., Kom, S., Kom, M., \& Terdahulu, P. (2017). Kesejahteraan Pedagang Batik Di Kota Surakarta. 4, 58-66.

Saputri, A. G. (2014). Analisis Kontribusi Usaha Kecil Menengah Di Kabupaten/Kota Provinsi Daerah Istimewa Yogyakarta. Jurnal Ekonomi (Je), 1-15. 
Silvia, Hanna Dan Syamsun, Muhammad Dan Kartika, Lidawati. (2015). Analisis Strategi Peningkatan Daya Saing Komoditas Kentang Di Kabupaten Karo, Sumatra Utara. Jurnal IImiah Pertanian Indonesia (Jipi)

Wibowo, D. H., Arifin, Z., \& Sunarti, . (2015). Analisis Strategi Pemasaran Untuk Meningkatkan Daya Saing Umkm (Studi Pada Batik Diajeng Solo). Jurnal Administrasi Bisnis, 29(1), 59-66. Retrieved From Http://Administrasibisnis.Studentjournal.Ub.Ac.Id/Index.Php/Jab/Article/View/117 2

Wignaraja, G., Jinjarak, Y. 2015. Why do SMEs not borrow more from banks? Evidence from the People's Republic of China and Southeast Asia. https://doi.org/http://dx.doi.org/10.2139/ssrn.2548916 